\title{
INTEREST AND PRINCIPAL: A FAILURE OF DEFINITION IN THE INTERNAL REVENUE CODE
}

The Internal Revenue Code provides that interest, consideration for the use of money, is taxable as income to the recipient ${ }^{1}$ and is deductible by the debtor when "paid or accrued." It does not provide, however, any criteria for determining whether a partial payment on an interest bearing debt is principal or interest. As a result, in determining when taxable income is realized, federal courts have applied local principles of contract law ${ }^{3}$ which allow the parties to determine whether a payment is principal or interest. ${ }^{4}$ In Robert H. Grics, for example, the Tax Court gave effect to a private agreement, enforcenble under state law, that $\$ 14,000$ paid on a debt consisting of $\$ 46,000$ principal and $\$ 27,000$ interest was principal and consequently not taxable as income. Similarly, courts have given effect to bookkeeping entries where both parties recorded the payment on the debt as principal, ${ }^{7}$ and have upheld an agreement to treat a payment as interest and therefore deductible, even though no accrued interest was due at the time. ${ }^{8}$ Thus, since a taxpayer's characterization of debt repayment as principal or interest is given effect, the parties are able to allocate income or deductions to years in which they choose to call any given payment principal or interest. Such taxpayers, accordingly, are able to exercise an unusual degree of control over their income tax liability, notwithstanding the well established principle that a taxpayer's earnings must "clearly reflect income" in a meaningful economic sense ${ }^{0}$ and that income cannot be avoided by anticipatory arrangements or contracts whose only function is to designate the year in which income is to be received or deductions to be taken. ${ }^{10}$ Since the present

1. INT. Rev. CoDE of 1954, § 61(a).

2. INT. Rev. CODE OF 1954, \& 163.

3. See, e.g., Estate of Paul M. Bowen, 2 T.C. 1, 7-8 (1943) (dictum); Robert H. Gries, 19 P-H Tax Ct. Mem. 383 (1950) ; cf. W. H. Hughes, 21 P-H Tax Ct. Mem. 704, 709 (1952).

4. Thus, where a creditor accepts a payment subject to the debtor's dircetion that it be applied to principal or to interest, such direction may be given effect, Kann v. Kann, 259 Pa. 583 (1918) ; Pindall v. Marietta Bank, 37 Val. 481 (Ohio 1839). And in the absence of direction or agreement as to how a payment is to be applied, the payment must generally be applied first to interest. Story v. Livingston, 38 U.S. 359, 370-75 (1839) ; cf. Wallace v. Glaser, 82 Mich. 190, 191 (1890). However, a creditor has been permitted to apply it as he chooses. Benson v. Reinshagen, 75 N.J. Eq. 358 (1909).

5. 19 P-H Tax Ct. Mem. 383 (1950).

6. Id. at 384-85 (figures are rounded).

7. Robert Hughes \& Co., 8 P-H Tax Ct. Mem. 171 (1939), rev'd on other grounts, 109 F.2d 720 (8th Cir. 1940); George S. Groves, 38 B.T.A. 727 (1938).

8. I.T. 3740, 1945-2 Cun. Bull. 109; John D. Fackler, 39 B.T.A. 395 (1939).

9. See Automobile Club v. Commissioner, 353 U.S. 180, 188-90 (1957); American Automobile Ass'n v. United States, 367 U.S. 687 (1961).

10. Cf. Lucas v. Earl, 281 U.S. 111 (1930), holding that taxpayer may not escape tax by such arrangements; Helyering v. Clifford, 309 U.S. 331 (1940), stating that "[arrangc- 
treatment with regard to debt repayments presents the possibility of unwarranted tax minimization, ${ }^{11}$ use of objective criteria for distinguishing interest from principal, and thus more clearly reflecting income, seems desirable.

Recognition of the parties' designation of a payment as principal or interest, under contract law, was established in cases which were unconcerned with the question whether a payment represented a return of capital or the realization of income. Rather, since characterization of particular payments as principal or interest may affect the amount ultimately required to liquidate the debt, the distinction between principal or interest in these cases was solely for the purpose of determining whether the debt had been fully repaid. ${ }^{12}$ Moreover, as the resolution of this issue-which could only arise where a debt bore simple interest ${ }^{13}$ _depended on the parties' characterization of the nature of payments, the courts naturally allowed the intent of the parties to prevail.

It seems clear, however, that what is recognized as a payment of interest under state law does not correspond, except fortuitously, with what would normally be considered income under the Internal Revenue Code, and that what is recognized as return of principal under state law does not correspond with what would generally be considered a tax free return of capital. The distinction between principal and interest in tax law is merely a special instance of the distinction between a return of capital and income. In distinguishing between a return of capital and income in other situations, courts have held that any payment received in a profitable transaction, regardless of the taxpayer's

ments], though valid under state law, are not conclusive so far as $\$ 22$ (a) [predecessor of $\S 61$ (a)] is concerned." Id. at 335.

11. Thus, the parties could agree to treat payments as principal in the early years of repayment if the creditor's tax bracket were higher than the debtor's, perhaps dividing the tax saving, and vice versa. Or, where the parties' income varied from year to year, they could agree to treat payments as interest in years when the creditor's income was relatively low and the debtor's relatively high.

12. See, e.g., Story v. Livingston, 38 U.S. 359 (1839); Wallace v. Glaser, 82 Afich. 190 (1890); Pindall v. Marietta Bank, 37 Val. 481 (Ohio 1839); Kann v. Kann, 259 Pa. 583 (1918).

13. Interest may be simple or compound. Simple interest is computed solely on principal unpaid at the interest date; compound interest is computed on both unpaid principal and unpaid interest, accrued in prior periods. When a debt bears simple interest, the total amount to be paid in liquidating the debt will be less if principal is paid off first than if each payment is applied first to interest then due. For instance if $\$ 1000$ is loaned at 10\% simple interest, and after the first year a $\$ 500$ payment is made which is applied to principal, then the payment required to liquidate the debt one year later will be $\$ 650$ ( $\$ 500$ principal $+\$ 100$ interest accrued in first year $+\$ 50$ interest accrued in second year). But if the first payment is applied first to interest to the extent possible, $\$ 660$ will be required ( $\$ 600$ principal $+\$ 60$ interest accrued in second year). Thus, litigation to determine whether a $\$ 650$ payment by the debtor has liquidated the debt depends on whether, according to the loan agreement, the first payment is required to be applied to principal or to interest.

Only where the debt bears simple interest, however, is this true. If compound interest were specified, the second payment would be $\$ 660$ in either case. If the first payment were applied to principal, $\$ 10$ of interest would accrue on the $\$ 100$ interest that remained unpaid in the first year. 
designation, must be allocated between income and capital. ${ }^{14}$ Thus, a taxpayer is not allowed to recover his entire capital investment before some income is deemed to have been received. It would seem that similar requirements would apply to payments of principal and interest. Under current tax practice, however, the parties to a loan agreement can determine, for any given repayment schedule, the years in which income is to be received. For example, if it has been determined that a $\$ 1000$ loan is to be repaid with two $\$ 600$ payments to be made one and two years after the date of the loan, the entire $\$ 200$ of income will be taxable in the second year if the loan agreement provides for $14.3 \mathrm{per}$ cent simple interest and requires that the payments be applied first to principal. But if the agreement provides for 13.1 per cent interest and requires that payments be applied first to accrued interest, then $\$ 131$ of income will be taxable in the first year and $\$ 69$ will be taxable in the second even though the repayment schedule-requiring two $\$ 600$ payments-is identical. In this way the judicious characterization of payments as principal or interest in the loan agreement may be used to minimize tax liability by allocating a given amount of income to years in which the creditor is in a relatively low tax bracket or the debtor is in a relatively high one.

It would seem, therefore, that state law, which allows the parties to choose their own terminology for the purpose of setting the amount of their loan, should not be determinative of tax liability. Most Code provisions are not to be taken as subject to state control or limitations unless the language or necessary implication of the section involved makes its application dependent on state law, ${ }^{15}$ and it is unlikely that Congress intended that state contract law govern the interest provisions of the Code, knowing that the parties could, as a consequence, fully control the extent to which any payment is taxable. Allowing the parties to determine what is principal or interest, moreover, seems contrary to the courts' solution in other analogous situations. For instance, in deciding whether an out-lay is an ordinary and necessary business expense rather than a capital expenditure, ${ }^{16}$ courts look to Treasury Regulations ${ }^{17}$ and judicind precedents, ${ }^{18}$ both of which furnish objective criteria that is not dependent upon state law or the taxpayer's intention. ${ }^{10}$ Because there is seldom any non-tax

14. Heiner v. Mellon, 304 U.S. $271,275-76$ (1938) (and cases cited at $275 \mathrm{n.3}$ ); cf. Treas. Reg. \& 1.61-6 (1957).

15. United States v. Pelzer, 312 U.S. 399, 402-05 (1941).

16. An ordinary and necessary business expense is deductible under the Code, whercas a capital expenditure is not. See INT. REv. CoDE of 1954, \& 162(a); see generally Cook, Repairs Expense Versus Capital Expenditures, 13 TAX L. REv. 231 (1958).

17. Treas. Reg. \& 1.162-4 (1958).

18. Cf. Midland Empire Packing Co. v. Commissioner, 14 T.C. 635 (1950).

19. Thus repairs are for the purpose of keeping property in good operating condition. See, e.g., Midland Empire Packing Co. v. Commissioner, 14 T.C. 635. (1950); American Bemberg Corp., 10 T.C. 361 (1948), aff'd, 177 F.2d 200 (6th Cir. 1949). Capital improvements, on the other hand, extend the life of the property, Illinois Merchants Trust $\mathrm{Co}_{0} 4$ B.T.A. 103 (1926), restore depreciated property, P. Dougherty Co., 5 T.C. 791 (1945), aff'd, 159 F.2d 269 (4th Cir. 1946), cert. denied, 331 U.S. 838 (1947), materially add to value, Hotel Sulgrave, Inc., 21 T.C. 619 (1954), or are part of a general scheme of recon- 
reason for taxpayers to distinguish between a capital expenditure and business expense, ${ }^{20}$ giving effect to the parties' self-determination in this situation would create a patent tax avoidance device. ${ }^{21}$ Similarly, numerous other characterizations of the taxpayer, especially those having no non-tax effects, are scrutinized and often rejected because they do not clearly reflect income. ${ }^{22}$

But if courts are not to follow state law and, thus, the agreement of the parties-because they do not purport to allocate economic income-then an alternative method must be adopted for determining when or what part of a payment should be taxed or deducted as interest. Since the object of such a determination is to reflect income clearly, it seems appropriate to use an objective technique that is not dependent on the wishes of the parties or on income tax considerations. Such a technique is available and is widely used, albeit for another purpose, by professional investors in appraising the merits of various alternative investment opportunities. Such investors assess various investments by determining and comparing the predicted yield or rate of return on each investment. ${ }^{23}$

Yield or rate of return is the uniform, annually compounded interest rate which the invested sum must earn to account fully both for any interest or dividends paid and also for any increase in the capital value of the investment. ${ }^{24}$ When such rate of return is multiplied by the total value of an invest-

ditioning, Joseph Merrick Jones, 24 T.C. 563 (1955), aff'd, 242 F.2d 616 (5th Cir. 1957). See generally Cook, stpra note 16. In borderline cases, however, a taxpayer's consistent accounting method may be given some weight. Cf. W. P. Brown \& Sons Lumber Co., 26 B.T.A. 1192 (1932), appeal dismissed, 68 F.2d 1022 (6th Cir. 1934).

20. The evident significance to taxpayers of the capital or expense alternatives is in fact that if an item is expensed, the related tax money is available as current working capital. On the other hand, if the item is capitalized, the expenditure tax-wise is generally recoverable through depreciation over a period of years, with a corresponding loss of interest value on related tax money.

Cook, sipra note 16 , at 232 .

However, there are times when non-tax considerations may be significant, as for instance, if the parties had agreed to buy and sell a business for a price related to its book value.

21. I.e., many taxpayers would treat all expenditures as deductible repairs rather than capital improvements, if such treatment would be recognized for tax purposes.

22. Thus the taxpayer's pro rata allocation of membership dues in monthly amounts was found to be purely artificial and ineffective for tax purposes, Automobile Club of Michigan v. Commissioner, 353 U.S. 180 (1957); arrangements that serve no business purpose will be ignored, Aldon Homes v. Commissioner, 33 T.C. 582 (1959); Higgins v. Smith, 308 U.S. 473 (1940); see also Helvering v. Hallock, 309 U.S. 106 (1940) in which the Supreme Court refused to apply local law in determining whether a conveyance created a taxable reversionary interest:

Such an essay in linguistic refinement would still further embarrass existing intricacies. It might demonstrate verbal ingenuity, but it could hardly strengthen the rational foundations of law.

Id. at 117 .

23. See generally Jordan \& Dougard, Investarents 271-88 (6th ed. 1952).

24. Compare definition of "net yield," Jordan \& Dougazs, op. cit. stpra note 23 , at 273. 
ment-the amount originally invested plus accrued earnings-at the beginning of a tax year, the product is the portion of the total income to be realized from the investment which is allocable to that tax year. And, although it is possible to allocate income on the assumption that the rate at which the investment produces income varies, even to the extent that all the income from a long term investment could be considered to be earned in a single year, the assumption made by professional investors of a constant rate of return seems far more reasonable. Thus the problem of allocating income requires a determination of the rate of return to be realized by the creditor from his loan. In the case of indebtedness bearing compound interest, the nominal interest rate and the rate of return are identical. Where, however, indebtedness bears simple interest, or the parties, without stipulating an interest rate, agree to liqutidate indebtedness by means of payments to be made in specified amounts at designated times, determination of the equivalent interest rate can be simply accomplished by reference to readily available compound interest tables. ${ }^{25}$

Such calculations thus provide an alternative to giving effect to the parties' characterization in determining when a payment on indebtedness constitutes interest. Under this alternative the rate of return would first be ascertained and would then be considered to be the interest rate on the indebtedness. An accrual basis taxpayer would accrue interest in conformity with this constrtictive compound interest rate; a cash basis taxpayer would treat any payment "in cash or its equivalent" as interest to the extent that interest, calculated in accordance with the constructive compound interest rate, has accrued but has not previously been treated as paid. Recognition of interest, as income or expense, would thus be restricted to the years to which income or expense is economically allocable and in which payments are actually made in the case of a cash basis taxpayer; it would, furthermore, insure that accrual basis taxpayers cannot, by agreeing to call a payment principal, avoid tax recognition in years in which income or expense is economically accrued. It should be noted, however, that since the amounts of various payments required under the loan agreement must be calculated on the basis of the interest rate stipulated in the agreement, separate accounts may be necessary for tax and non-tax purposes. The two accounts would show different amounts of principal, interest, and total amounts owing at any time except that, of course, both would agree as to the point at which the debt was fully repaid.26

25. See, e.g., RtDer, The Mathenatics of Investment 127-48 (1938); Giunt, Princtples of Engineering Economy 597-613 (3d ecl. 1950). For example if $\$ 1000$ is loaned at $7 \%$ simple interest for 10 years, principal and accrued interest to be paid in the tenth year, the amount to be repaid at that time will be $\$ 1,700$. By interpolation from tables in RIDER at 130-31, or in GRANT at 607-08, the equivalent annual compound interest rate is $5.45 \%$.

26. The nature of the two accounts will be made clearer by the following example. Assume that $\$ 1000$ is loaned at $7 \%$ simple interest on the understanding that $\$ 600$ will be paid in one year and credited to principal, the remaining principal and interest to be repatid at the end of the following year. The constructive compound interest rate is $6.681 \%$, tables in RIDER, GRANT, op. cit. supra note 25 . Prior to the $\$ 600$ payment the tax account would 
The suggested method of ascertaining when interest is paid or accrued must be modified in a few special cases. For instance, if the repayment schedule cannot be determined because the parties agreed that the debt should be liquidated at an undetermined future date, then a constructive compound interest rate cannot be computed. ${ }^{27}$ In this situation, it would seem that each payment should be treated as part return of principal and part interest in proportion to the ratio of the amount of the loan to the total amount of income to be earned. ${ }^{38}$ Similarly, when a debt bears simple interest but the time of repayment is not known, a constructive compound interest rate cannot be determined. 20 In this case it seems that to determine what part of a payment constitutes interest for tax purposes, each payment should be treated as applied first to any accrued simple interest which has not been previously treated as paid, even though the parties may agree to apply the payment to principal for the purpose of determining the amount of future payments. ${ }^{30}$

The suggested treatment is not the equivalent of putting a cash basis taxpayer on an accrual basis as to interest, since no amount is taxed as interest unless an actual payment is received; moreover, this treatment preserves the parties' right under contract law to characterize any payment as principal for the purpose of reducing the base for computing future interest. However, such a treatment of partial payments on indebtedness, by using the concepts of rate of return and constructive compound interest rates to allocate interest income, deprives a taxpayer of one justifiable advantage he now holds under the present practice of following state law. Where a taxpayer has reason to believe a loan

show $\$ 1066.81$ owing ( $\$ 1000$ principal and $\$ 66.81$ interest); the non-tax account would show $\$ 1070$ owing ( $\$ 1000$ principal and $\$ 70$ interest). Since the $\$ 600$ vould be applied in part to interest for tax purposes, but entirely to principal according to the loan agreement, the tax account after that payment would show $\$ 466.81$ owing (all principal), and the nontax account would show $\$ 470$ owing ( $\$ 400$ principal and $\$ 70$ interest). Immediately prior to the second payment, the tax account would show $\$ 498$ owing (\$466.81 principal and $\$ 31.19$ interest); and the non-tax account would show $\$ 498$ owing ( $\$ 400$ principal and $\$ 98$ interest- $\$ 70$ accrued in the first year and $\$ 28$ accrued in the second year). On payment of $\$ 498$ both accounts will show the debt to be fully repaid.

27. The constructive compound interest rate can be determined only where the sum to be repaid and time of repayment are known, except that only one of these two variables is needed if a simple interest rate is also known.

28. Such a method of allocating a receipt to return of capital and income is common in recognizing gains realized on the sale or exchange of a portion of a capital asset. Sce Treas. Reg. § 1.61-6(a), Example (1) ; Heiner v. Mellon; 304 U.S. 271 (1938) (and cases cited at 275 n.3).

29. Since without the time of repayment the sum to be repaid cannot be known, the requirements described in note 27 supra cannot be met.

30. Thus, if $\$ 1000$ is loaned at $7 \%$ simple interest on the understanding that all payments will be applied first to principal, $\$ 50$ is in fact paid in the first year, and $\$ 100$ is in fact paid in the second year, $\$ 50$ will be taxed as interest in the first year (since $\$ 70$ interest had accrued, the entire payment will be treated as interest), and $\$ 86.50$ will be taxed as interest in the second year ( $\$ 20$ interest accrued in th first year but not previously treated as paid plus $\$ 66.50$ interest accrued on $\$ 950$ principal-the first payment having been applied to principal for the purpose of calculating the amount still due). 
may not be repaid in full, he may choose to apply all payments first to principal to avoid declaring taxable income on what may ultimately be a losing transaction. ${ }^{31}$ Although this privilege will be lost if the suggested treatment is adopted, the uncertain creditor can still avoid declaring income by making a binding waiver of his right to interest. A broader privilege seems incongruous since, in the similar case of bonds, all interest must be declared as income even where the bond appears incapable of being redeemed ${ }^{32}$ and even though no loss would be allowed until the bond became totally worthless. ${ }^{33}$

31. Thus, in Robert H. Gries, 19 P-H Tax Ct. Mem. 383 (1950), the creditor, apparent1y fearing that his loan would never be repaid in full, agreed with the debtor that payments would be applied first to principal. The Tax Court held that the payments did not constitute income.

32. Herbert Payson, Jr., 18 TCM 686, 689 (1959).

33. If any security which is a capital asset becomes worthless during the taxable year, the loss resulting therefrom shall ... be treated as a loss from the sale or exchange ... of a capital asset.

INT. Rev. Code of 1954 § 165(g). See also Merrill Trust Co., 21 B.T.A. 1395 (1931). 